\title{
SOURCES OF CADAVER USED FOR DISSECTION AT THE IBADAN MEDICAL SCHOOL, NIGERIA - Analysis of a three-year data
}

\author{
OSUAGWU.F.C , IMOSEMI I.O., OLADEJO.O.W. \\ Department of Anatomy, College of Medicine, University of Ibadan.
}

\begin{abstract}
Our experience with cadaver collection at the Department of Anatomy, University of Ibadan, Nigeria between $9^{\text {th }}$ of February 1998 and $11^{\text {th }}$ of October 2001 is presented. A total of twenty-eight bodies were collected from the State Hospital, Ring Road during this period viz: twenty-six were males (92.9\%) and two females (7.1\%). Twenty-two (78.6\%) were suspected bandits who died during gun duel with law enforcement agents while six $(21.4 \%)$ were bodies that were accident victims and unclaimed bodies. Four of the unclaimed bodies were males (66.7\%) while females were two (33.3\%). The majority of bodies that were those of suspected bandits were males and they were twenty-two $(100 \%)$ while no female (0\%) was recorded. No record of voluntary donation of cadavers for anatomy dissection was documented. Adequate documentation is advocated for the giving hospital and the receiving medical school. It is suggested that anatomists embark on a more aggressive enlightenment campaign to the society to encourage those that might be willing to voluntarily will their body after dying to further the quest of knowledge to do so.
\end{abstract}

Keywords: Cadaver collection, Ibadan, Dissection

*Correspondence: ferdnand_o@yahoo.com

\section{INTRODUCTION}

Anatomy is a unique subject because the object of our study is the human body. Thus the material mainly utilized for practical sessions are dead humans (cadavers). The collection of these cadavers has come a long way because most societies initially outlawed the utilization of the remains of the dead for any purpose except that of internment. The use to which most societies will allow human materials to be is relative to that society's moral values. As such justification and the bounds for the use of cadavers are set by the society (Jones, 2000). But as man developed more complex societies and realized the need to further the quest of knowledge, it became more imperative that the earlier superstitions that barred the use of human remains for study has to be discarded.

The Anatomy Act of 1984 was one of the enabling legislation that would clearly state the conditions that would guide the utilization of human remains for dissection in United Kingdom. The Anatomy Act is highly regulated with a government appointed Inspector who visits Anatomy Departments regularly (The Department of Health, 2001). Despite the fact that this legislation has aided the art of dissection a lot of grey areas still need to be ironed out and the countries in the developing world like Nigeria seem to be lagging behind their Caucasian counterparts in enacting their own enabling regulations.

The collection of cadavers has gone through the phase of grave robbing, through 
the era of use of unclaimed bodies and use of condemned criminals to use of bequeathed bodies by those who willingly donate their body for dissection. The scenario painted above has operated mostly in developed countries. The Anatomy schools in the developing world seem not to have caught up with the voluntary bequeathing of bodies.

The aim of this study was to try and evaluate the source of cadavers for a typical Anatomy Department in Nigeria and to categorize the type of people most likely to end up on the dissecting table and discuss the ethical issues that arise therein.

\section{MATERIALS AND METHODS}

The logbook of the cadavers donated to the Department of Anatomy, University of Ibadan was reviewed at one of the main sources of cadaver to the Department - Oyo State Hospital at Ring road, Ibadan, Nigeria. Due to the poor record keeping of both the donor, the State Hospital Ring Road and the receiving Department, we were only able to see the records between $9^{\text {th }}$ of February 1998 and $11^{\text {th }}$ of October 2001.Thus this period was subjected to review.

Data retrieved from each patients record included sex of the patient, categorization whether it was an unclaimed body or whether it was a suspected criminal. The age could not be ascertained from the records for obvious reasons.

Data was analyzed by simple frequency and percentages.

\section{RESULTS}

A total of twenty-eight cadavers were documented as to have been given to the Department of Anatomy, University of Ibadan by the State Hospital Ring Road between the $9^{\text {th }}$ of February 1998 to $11^{\text {th }}$ of October 2001. The distribution is shown in Figure 1.

Twenty-six of these bodies were males and this represents ninety-three percent $(92.9 \%)$. Two were females and this represents seven percent $(7.1 \%)$ of the total $(m: f=1: 13)$. Twenty-two were bandits and this represents seventy-eight point six percent $(78.6 \%)$. There were no documented cases of female robbers $(0 \%)$. Unclaimed bodies that died during road traffic accidents were six $(21.4 \%)$. Four $(66.7 \%)$ of the unclaimed bodies were males while two $(33.3 \%)$ were females. $m: f=2: 1$.

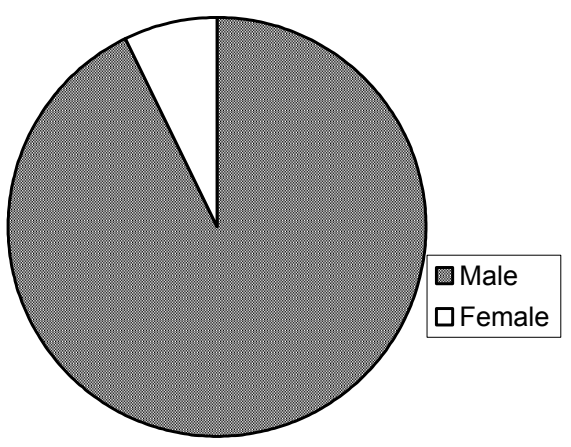

Fig. 1a. Distribution of the cadaver collection from the Ring road state hospital by sex

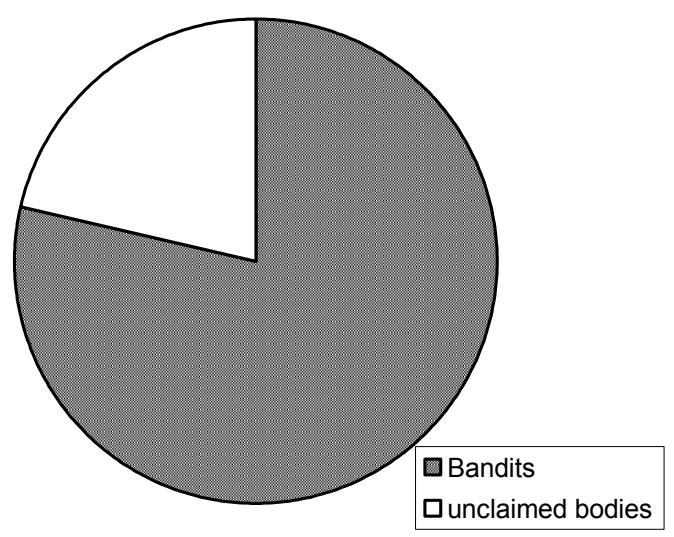

Fig. 1b. Sources of the bodies released

\section{DISCUSSION}

The main preponderance of criminals that lost their lives in gun duel with law enforcement agents suggests that most of the cadavers on our dissecting tables are criminals and in situations where this does not obtain then, they are bodies of unclaimed accident victims. 
African Journal of Biomedical Research 2004 (Vol. 7) / Osuagwu, Imosemi and Oladejo

The high percentage of males among our cadavers might be due to the fact that males are more likely to be involved in Acts that may involve gun duels

This male-female disparity might affect the medical students ability to get adequate dissecting exposure to female structures like breast, pelvic viscera like uterus and female perineum, thus it may be worthwhile to prosect more specimens to correct this or to acquire more visual aids like CD-ROMs, video tapes on this region.

The inability of our Medical Schools to attract voluntary donation of bodies for purpose of dissection might be due to poor social acceptance of such acts presently. Thus anatomists need to embark on a more aggressive enlightenment campaign to the society to encourage those willing to voluntarily will their body after dying to further the quest of knowledge to do so. The perceived benefits of this act need to be set alongside the environment in which the dissection is to be conducted. Jones (1994) had suggested that dissection should be carried out in an 'orderly, quiet, and descent manner', undoubtedly reflecting the dignity and respect to be accorded the dead human body. Without this, it would be difficult to attract any donor.

The appalling documentation that was observed between the donor State hospital and the receiving department might be due to the prevailing legal ambiguity or lack of clarity as justification for using human material without adequate consent (MacDonald, 2002). We suggest that adequate legislative procedure be put in place for proper documentation for all giving hospitals as well as the receiving medical schools.
A common theme emerging in recent recommendations is that anonymous tissue or organs may be used for teaching and research purposes without consent (Wertz, 1999). However the corollary to this assertion should be that anatomists should embark on aggressive enlightenment campaign to educate the populace on the need for informed bequeathing of bodies by those who might be willing to do so and once this is appreciated the role of informed consent follows automatically.

Finally there is need to advocate for the enactment of appropriate legislation to guide the way and manner human remains are handled when being utilized for dissection purposes and research.

\section{ACKNOWLEDGMENT}

The authors acknowledge the assistance of the Medical Officer-in-charge of the Pathology Unit of the State Hospital Ring road for allowing us access to their mortuary log book, Mr. I.O.Olatiregun, the Chief Technologists of the Department of Anatomy and Dioru Mirikae for typing the manuscript.

\section{REFERENCES}

Jones D.G. (2000).Speaking for the dead: Cadavers in biology and medicine.Ashgate: Aldershot.

The Department of Health. (2001). The removal, retention and use of human organs and tissue from postmortem examination. London: Her Majesty's Stationary Office.

Jones D.G. (1994). Use of bequeathed and unclaimed bodies in the dissecting room. Clin. Anat; 7.102-107.

MacDonald J. (2002).Mortician may have sold body parts. The San Diego Union-Tribune. Feb.22.

Wertz DC. (1999). Archived specimens: a platform for discussion. Comm Gen; 2:51-60

Received: November, 2003

Accepted in final form: March, 2004 